ORIGINAL SCIENTIFIC PAPER

711.4(497.11)"1815/1910"(084.3)

908(497.11)"1815/1910"

DOI:10.5937/ZRFFP45-9251

MARTA M. VUKOTIĆ LAZAR ${ }^{1}$

UNIVERSITY OF PRIŠTINA WITH TEMPORARY HEAD-OFFICE

In KoSOVSKa Mitrovica, FACULTY OF PHILOSOPHY

DEPARTMENT OF HISTORY OF ART

NATAŠA M. DANILOVIĆ HRISTIĆ ${ }^{2}$

URBAN PLANNING INSTITUTE OF BELGRADE

\title{
THE GROWTH AND DEVELOPMENT OF BELGRADE IN THE PERIOD FROM 1815 TO $1910^{3}$
}

ABSTRACT. Belgrade has been devastated and redeveloped for countless times. Various cultures, nations and conquerors left different urban matrices and physical structure. The groundwork for conceptualization and research of the urban matrix as an essential element of Belgrade's urban morphology are graphic presentations - the old maps and plans ${ }^{4}$. Appreciating strategic significance Belgrade had up till $19^{\text {th }}$ century, they were mainly elaborating Belgrade Fortress area, while civil settlement - the Borough inside the Trench, a small typically oriental town (Kurtović Folić, 2000, pp. 15-21) was presented in general sketches.

This paper deals with breakthrough conceptions about planned construction of Belgrade inside and outside of the fortress moat from the beginning of the $19^{\text {th }}$ till the beginning of the $20^{\text {th }}$ century. The ruling period of Prince Miloš Obrenović was especially emphasized, when planned construction of the new, geometrically regulated Belgrade settlement in Western Vračar (outside the Trench) started and was supposed to be connected with the city center of the Serbian Belgrade (inside the Trench) around the current Sabor-

\footnotetext{
marta.vukotic@gmaill.com

natasa.danilovic@urbel.com

3 This paper was submitted on 14 August 2015 and accepted for publication at meeting of the Editorial Board held on 8 October 2015.

4 Belgrade: Maps and Plans from the $18^{\text {th }}-21^{\text {st }}$ century. Belgrade: Urban Planning Institute of Belgrade.
} 
na church, via two already existing streets - Abadžijska Street and Fišeklijska Street. Prince Miloš in 1815., obtained from Marašli Ali Pasha the Savamala area with the formed village on so called slope, that was soon to be destroyed and set on fire upon his order, with the goal of building "a new Serbian Belgrade". (Krasojević, 2004) The expelled landowners gained the opportunity to settle down on the Danube side, in the village of Palilula. In the third and the fourth decade of the $19^{\text {th }}$ century there started the planned guidance of population of respective urban areas and regulation of some tracings in Savamala and Terazije as far as the Batal Mosque, forming on the slopes of Savamala and Western Vračar a new part of Serbian Belgrade, beyond the Trench with several new "čaršija". (Škalamera, 1974. pp.9-14)

In the period 1835-38, Prince Miloš began developing some prominent edifices and institutions of the restored Province of Serbia in this Belgrade area, and his son, Prince Mihailo Obrenović, continued with the development of this area after 1860.

KEY WORDS: urban heritage, architecture, history, morphology.

INTRODUCTION

The development of Belgrade, as the leading regional urban center, is a process conditioned by its specific geographic location and intensive historical occurrences. Urban planning, by its nature faces mainly future, but cognition, experience and lessons from the past could significantly contribute to better perception and insight of realistic solutions, avoidance of failures and special dedication to certain topics. Some issues of the $19^{\text {th }}$ century city were translated into the $20^{\text {th }}$ and the $21^{\text {st }}$ century, so if we are willing to continue with construction and development of the city, we should review the historical facts that led to its present appearance.

Belgrade, the capital city of Serbia, is situated in the central part of the Balkans and in the southern part of Podunavlje - the Danube river basin. By its position, the area of Podunavlje belonging to Belgrade's administrative territory could be divided into Srem, Banat and Šumadija regions and according to the same clue Belgrade's Posavina is divided into Srem and Šumadija regions of Posavina. It seems that the position of the City on the confluence of the rivers the Sava and the Danube, where the Pannonia plain meets hilly Šumadija and at the border of the two former, the Ottoman and the Austro-Hungarian empires, determined in advance the urban structure of the City. (Vujović, 1986) 
The territory of Serbia has been under the Turkish rule for more than four centuries and their influence on urban and rural structures, architectural heritage and housing is obvious, as well as on numerous things in everyday use, etc. During the reign of AustroHungary, the Austrians aspired to redevelop Belgrade from the oriental town into the European city. They conquered the Fortress thrice: in 1688, 1717 and in 1789 and lost it thrice: in 1690,1739 and in 1791. Each period of their rule was bringing ethnic and urban changes. The Belgrade Fortress is the most significant monument in the entire urban heritage of Belgrade, as a testimony about continuity and life span of the settlement. Nowadays, the Fortress stands erected on the foundations of the Roman-Byzantine castrum. (Tričković, 1973. pp. 49-87) Stone bastions, towers and gates are mostly the remains of the Serbian-Hungarian fortress from the 14th and 15th century. The New Age started with the AustrianTurkish war and during the $18^{\text {th }}$ century the Fortress was reconstructed thrice. Belgrade was transformed from the commercial and civilian city into the military camp. Under the Austrian occupation 1717-1739, followed by the constructions of the new modern fortifications, the Belgrade Fortress was one of the sturdiest military strongholds in Europe, built according to the projects of the General Nikola Doksat de Mores, a Swiss in the Austrian military service. The demolition of all the newly erected fortifications preceded the return of the Turks to Belgrade in 1740. Despite Turkish resistance, most of it was demolished; still, the traces remained, as for example in Varoš trench existing since the second half of the $19^{\text {th }}$ century. (Bajalović-Hadži Pešić, 1977)

In the middle of the 19th century, the period of rise of the academicism style in architecture and destruction of the medieval bastions in Europe, the epoch of great transformations and urban reconstructions started. That was a period of origination of the avenues, boulevards, squares, parks and open public spaces, provided for monumental public buildings. (Perović, 1997. pp. 276-349) Those new florid palaces of state institutions, built as independent multi-level structures, represented the symbols of the departing late-feudal social elite and the rising civic-liberal movements. Together with the monuments of the nation founders, these buildings supported the significance and legitimacy of the social structure of Europe. (Kadijević, 2005) The abandonment of the oriental tradition and turning to the standards of developed Europe, represented the strategic goals of the urban planners and 
architects, owing to whose commitment in the second half of the 19th century, the government architectural-town planning unit was formed and systematized the building legislative. (Maksimović, 1978. pp. 31-70)

\section{PERIOD OF LIBERALIZATION AND EUROPEANIZATION, 1815-1867}

Since the end of the $18^{\text {th }}$ century until the 1820 s Belgrade was not developed spatially and neither were there the conditions for the transformation of the oriental structure inside the Trench. The Austrian borough was demolished by the Turks, though new buildings have not been erected. Belgrade was called the Turkish casaba - town with good reason, and Serbian liberators found it in such a shape in 1806. Since 1815 until the 1870s Belgrade was surrounded by the Trench and palisades. (Kojić, 1976) The line of the Trench of those days is partly preserved in broken sections of Obilićev, Topličin and Kosančićev venac and towards the Danube in the line of Skadarska Street. The entrance to Borough was via the Fortress gates. The Sava and the Šabac gates were at the Sava port, the Varoš gate at the crossroads of today's Pop Lukina street and Kosančićev venac, the Stambol gate in the space of today's Republic Square (near the monument of Prince Mihailo), then the Carska or the Vidin gate, near today's Church of Alexander Nevski, and the Temišvar gate near the Danube.

Up till the Second Serbian Uprising Belgrade was situated within the limits of the Borough inside the Trench. Afterwards, in the 1830s Belgrade was spreading, though not as the borough but through the suburbs: Savamala and Palilula, at the location of the demolished baroque settlements, constructed once according to the plans: the Lower Serbian borough and the German borough "Carlstadt». Within the borough, there is a clear distinction between predominantly Serbian and predominantly Turkish area, as well as the Belgrade fortress kept by the Turkish military garrison. The Serbian part of the borough was established around the old church of St. Archangel Mihailo and the former residence of Prince Miloš, where the Residence of Princess Ljubica and today's Saborna church (Serbian Orthodox Church) would be built afterwards. 


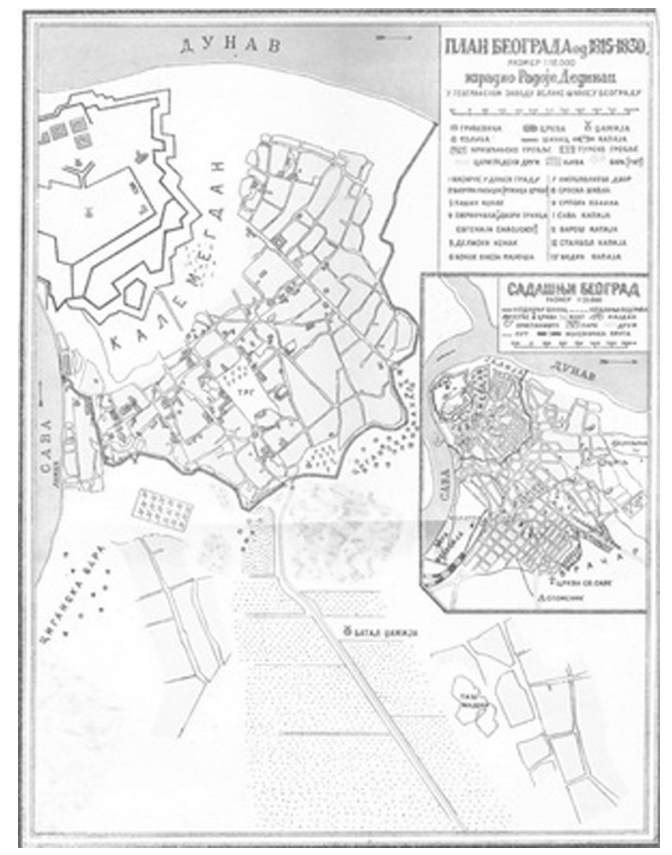

Figure 1. The Plan of Belgrade 1815-1830, elaborated By Radoje Dedinac (1880-1913), APPROXIMATELY IN 1901. APPENDIX TO THE BOOK OF JOAKIM VuJIĆ «PUTEŠESTVIJE PO SRBIJI»

(TRAVELING THROUGH SERBIA)

Radical changes in the development of Belgrade took place during the $19^{\text {th }}$ century. The urban development of Belgrade reflected necessarily the tactics and strategies of the national and local government policies. (Bojović, 2002, pp 109-130) Politically, together with Serbia, it was on its way to full independence, and the rivers the Sava and the Danube became the state borders. After the Second Serbian Uprising the borough around the Saborna church began to change, then to spread towards the Sava riverside area. Two suburban settlements were previously established: Savamala, on the Sava slope and Palilula below Tašmajdan on the Danube side. Organic structure of the Serbian borough outside the Trench was spontaneously developing with settlement alongside the old transport routes, and with time separate settlements were merging in. The 1830 s were characterized by the planned settlement of the certain parts of Belgrade and by regulation of particular sections in Savamala and in Terazije as far as the Batal Mosque. (Dervitchevitch, 1939; Đurić-Zamolo, 1977) 




FIGURE 2. BELGRADE IN THE FIRST HALF OF $19^{\text {TH }}$ CENTURY, 1850, AFTER THE FIRST PLANNED EXPANSION. THE MAP WAS PREPARED BY ŽELJKO ŠKALAMERA, 1973. PUblishED IN: “URBANIZAM BEOGRAD, 26”, URBANISTIČKI ZAVOD BEOGRADA, BEOGRAD 1974. 
According to the Sultan's Hatišerif - the Charter from 1830, Serbia gained some autonomy under the Ottoman sovereignty and Prince Miloš became the hereditary Prince. The Turks were hastily leaving Belgrade, while the influx of the Serbian population from Serbia, Vojvodina and occupied territories under the Turkish rule was progressively greater. The forth decade of the $19^{\text {th }}$ century is significant in re-established Serbian Principality for its pioneering enterprises in the development of settlements and construction of the public buildings, though also by the Prince's aspirations to develop and reconstruct Serbia according to the model of the developed European countries.

In 1834 Prince Miloš made the decision to move the Serbian capital from Kragujevac to Belgrade, leading to planned foundation and construction of the so-called New Serbian Belgrade. For several reasons the old Borough inside the Trench was not appropriate for erecting other public buildings: due to the lack of the unoccupied land, generally derelict and underdeveloped space, though in the first place due to the vicinity of the Fortress, still kept by the Turks. The danger of the Turkish cannons from the Fortress influenced the Prince to make the decision in favor of gradual migration and removal of the Christian population from this part of the City to the vacant area of the slopes towards the Sava.

Prince Miloš comprehended very soon that Serbian builders from Zemun and Pančevo were not skilled enough to realize his ambitious plans and ideas for the new constructions. Neither Hadži Nikola Živković, (1792-1870) has gained the Prince's confidence, although he was the first qualified builder of the Miloš's renewed Serbia, the builder of "The Residence of Princess Ljubica in Belgrade" (1829-31), the first representative building in the center of the Serbian part of the Borough inside the Trench in the entrance sector after the Varoš gate. (Dimitrijević, 1986)

That was the reason why the Prince wished to bring the builders over from Austria to Serbia, with the task to build the new public palaces in the New Borough, the buildings of Sovjet - the Court of Justice and the Court, after the model of the classic buildings in Budapest and Vienna.

The Slovak Frantz Janke, a construction engineer, came to Belgrade from Vienna in 1834, on recommendation of Cvetko Rajović, the Head of the City Administration. He became the first «pravitelstveni indžinir» - construction engineer at the «Popečiteljstvo vnutrenih dela» - Ministry of Interior, where he 

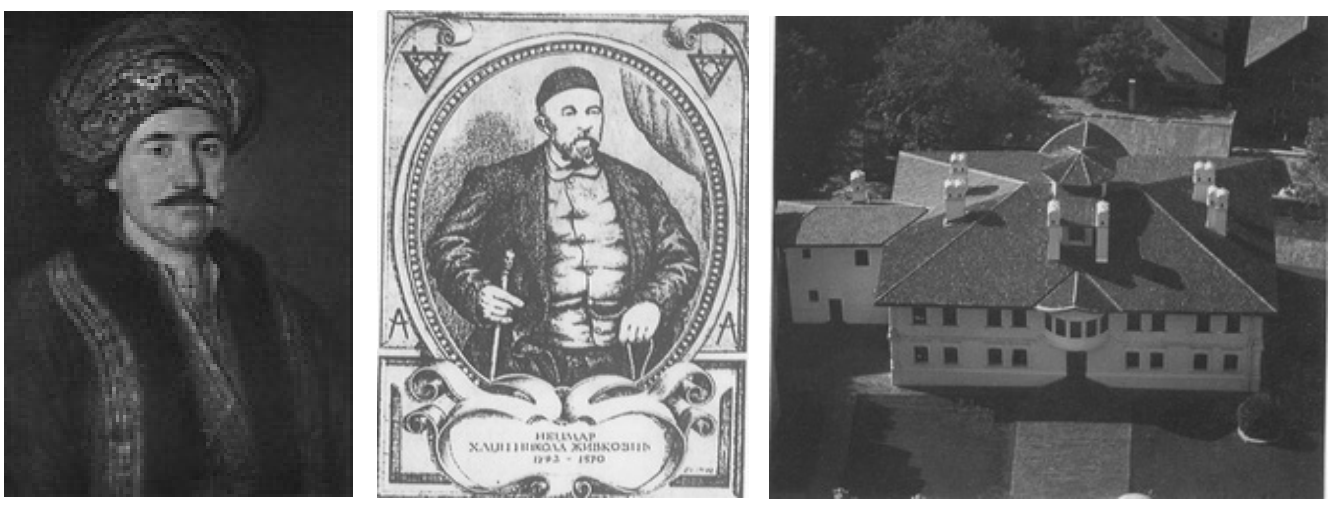

Figure 3. A. PRince Miloš ObRenović (1780-1860), PrinCE OF SERBia (1815-1839 AND

1858-1860),

B. HADŽi NiKola ŽIVKović, THE FIRST QUALIFIED BUILDER IN THE NEW SERBIA UNDER PRINCE MiLoš

OBRENOVIĆ,

C. The Residence of Princess Ljubica (1788-1843), the Wife of Prince Miloš Obrenović. It is A BUILDING SHOWING THE TRANSITION FROM THE ORIENTAL TO THE WESTERN EUROPEAN ARCHITECTURE

STYLE.

spent 9 years, until 1843. Besides architectural, Janke was dealing with construction and urban planning pursuits. He was working on the streets construction, regulation of the Sava port and constructions of embankments and bridges.

With the arrival of Frantz Janke, the conditions for planned realization of the Prince's urban planning ideas were fulfilled, so in the 1840 s the first Serbian urban plan of the New Borough was elaborated. Conception of the plan was in accordance with the modern urban planning models at the time, orthogonal, grid pattern with big blocks, provided for peripheral constructions and with the long and wide streets. In relation to the Borough in the Trench and up till then organic spreading and partly regulated settlements outside the Trench - in the Sava slope, Terazije, Skadarlija and Palilula, this urban plan signified entirely the new and prospective directions of further urban development. The plan scope related to the area between Tašmajdan and Mokroluški creek with parts of Savamala and Western Vračar. The plan of the New Borough doubled the city space and created urban planning groundwork for the development of Belgrade in the second half of the $19^{\text {th }}$ century, tripling its population during the period. (Škalamera, 1967, pp. 169-201) 
The lack of referent plans for studying the first half of the $19^{\text {th }}$ century is illustrated by the fact that from the last decade of the $18^{\text {th }}$ century more than a hundred various plans of Belgrade have been known and from this period only about twenty. Among them, the special place is held by the plans being a testimony to the urban planning activities in Serbia. Among numerous plans created by „measuring of the alleys" only five fragmentary surveys, dealing with determining of particular sites, land use and laying down of the new streets are preserved. All the five are signed by Frantz Janke and kept in the Archives of Serbia. The most significant among these plans is the one from 1842, when Belgrade became the capital of the Serbian Principality. The plan shows the biggest part of the newly planned borough between the old St Mark's church in Tašmajdan and the building of Sovjet, today's Birčaninova Street. It is obvious that it is the abstract from a wider and integral project, suggesting the existence of a regular urban plan, used for laying down and partial settlement of the new wide streets and city blocks between today's Boulevard of King Alexander and Western Vračar in the first half of the $19^{\text {th }}$ century. Urban structure of the new Belgrade was in the spirit of the developed European countries, and the main urban tracings from the period, the streets Kneza Miloša, Boulevard of King Alexander and Nemanjina - comprise a precious heritage from the pioneering period of the modern Serbian urban planning.

The rest of the kept Janke's plans - surroundings of the Saborna church from 1841, part of Zeleni venac as far as the Big brewery from 1840, part of Terazije as far as today's street of Kraljice Natalije, as well as the plan of the Lyceum from 1841 - are the illustration of the planning activities in the period. (Nestorović, 1954. pp. 159 174)

The oldest known plan, showing integrally, though in general, the situation of Belgrade after realized planned spreading in the first half of the $19^{\text {th }}$ century, is Captain König's plan from 1854. The plan analytically shows construction density of Belgrade and includes some of the important public buildings in the New borough.

All the mentioned plans are not sufficient for making an integral picture of the urban growth of Belgrade in the first half of the $19^{\text {th }}$ century. These plans lack the basic elements: detailed distribution and number of buildings, houses and other structures from that time. Still, together with other available archive material and illus- 


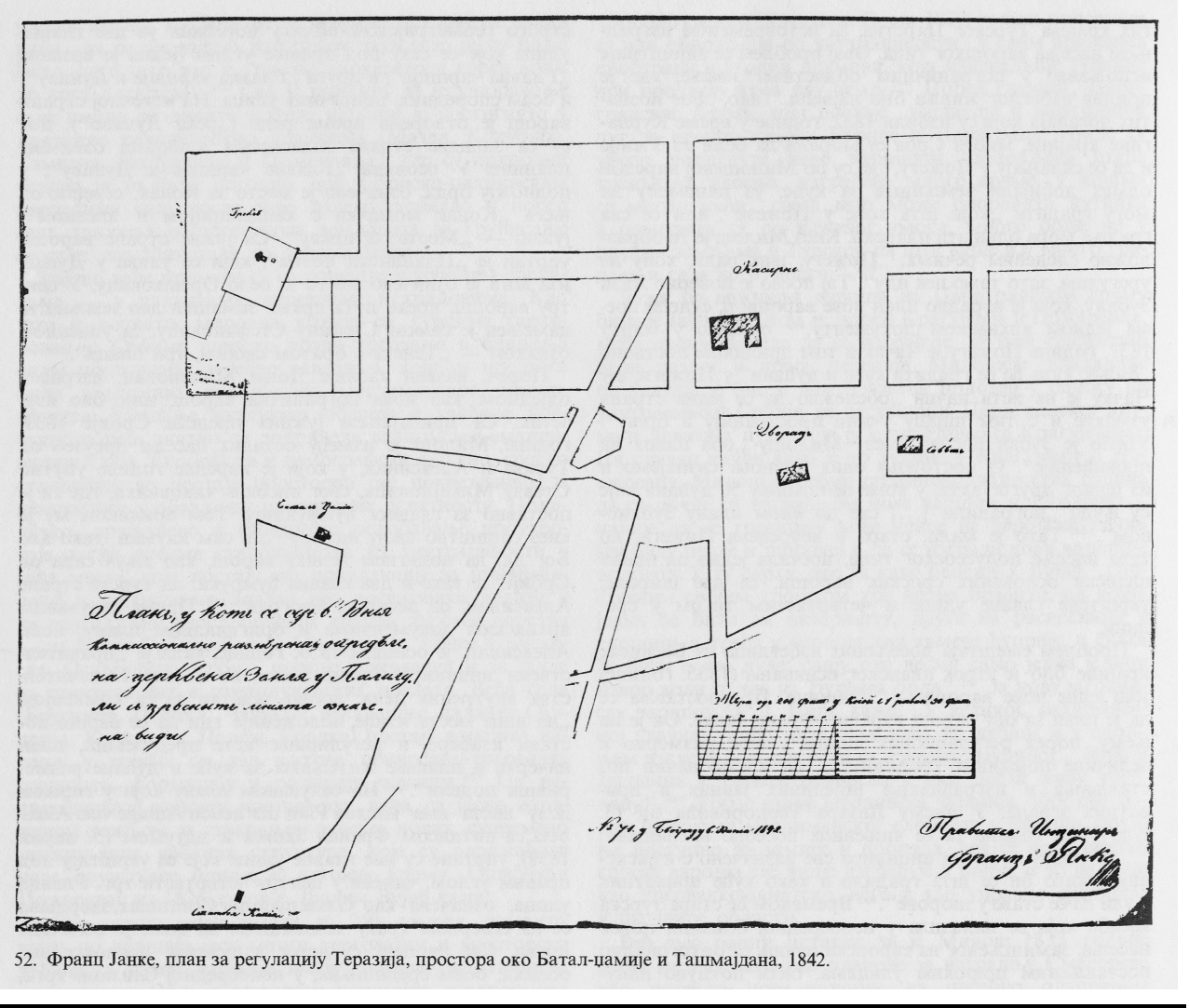

Figure 4. Frantz Janke, Regulation Plan of Terazije, the sPace around the Batal-Mosque AND TAŠMAJDAN, 1842. THIS IS THE MOST SIGNIFICANT JANKE'S PLAN AMONG THE FIVE SIGNED BY HIM AND SAVED UP TILL NOW, KEPT IN THE ARCHIVES OF SERBIA, SIGN. AS, MUDS-P-560/842

trations, it is possible to create a picture concerning urban development of today's Central zone of Belgrade.

Since the end of the 1950s the attempts for laying down the rules for the basic regulation and efforts to specify the further growth and development of the city have become rather intensive. First such plan was prepared for Paris in 1851 by Georges-Eugene Haussmann, after that example was followed by Barcelona in 1859 (Perović, 1997, pp. 276-349) then Berlin and Rome in 1873 The fact that Belgrade got the plan in 1867 aligns it in the order of European cities that are following the trends in urban planning and city modeling. (Stojanović, 2008) By the end of the first half of the $19^{\text {th }}$ century, the architecture in Belgrade was within the boundaries of the classicism, but it was possible to notice some new influences 




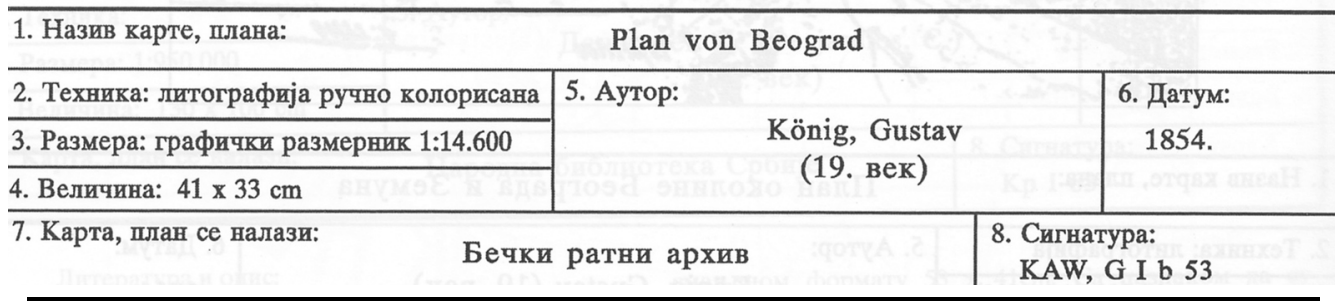

FigURE 5. KÖNIG'S PLAN (GUSTAV KÖNIG), VIENNA WAR ARCHIVES, 1854, SIGN. KAW, GIb53

that were popular in this period in the European architecture. The overall European architecture of the $19^{\text {th }}$ century will be marked by the ideas of eclectic style. 


\section{PERIOD OF URBANIZATION, GROWTH AND SPREADING OF CITY LIMITS, 1867-1910.}

For further urban development and transformation of Belgrade, the Agreement from 1862, about the obligation of forced emigration of the Turkish population from all the settlements in Serbia, the withdrawal of the Turkish army from the Serbian strongholds and finally the symbolic presentation of the Belgrade town keys to Prince Mihailo in 1867 at the Kalemegdan, was of an exceptional importance.

From that period there is the "Turkish town and borough plan surrounded by Trench" - 1863, preserved in the National library of Serbia. This precious cartographic document related to Belgrade from the end of Turkish reign in Serbia includes the titles of 172 various structures and localities in Belgrade and Borough, as well as census of all the houses in the Borough, with distinction of ethnic groups of the owners, i.e. the inhabitants who belonged to (the Serbs, the Jews and the Turks). The purpose of the plan was mainly political.

The period from 1867 until the beginning of the First World War is of utmost significance for the growth and development of Belgrade. From that period almost all good as well as bad characteristics of the streets network, city blocks, squares and parks of today's central parts of Belgrade (besides streets traced at the time of Prince Miloš, such as today's streets of Kraljice Natalije, Gavrila Principa, Kneza Miloša, Boulevard of King Alexander etc.) can be derived. The beginning of the period was marked by the final surrender of Belgrade to the Serbian hands, as well as elaboration of the first integral urban plan of the Borough inside the Trench. During these years the laws concerning constructions were passed, witnessing efforts of the state administration to offer the coherent legal framework for building activities. In the same period, legislation concerning urban planning and regulation of settlements was passed as well.

After buying out a great number of parcels and houses from the Muslim population, the Government made the decision about the overall reconstruction of the old part of the Borough inside the Trench. The Ministry of Constructions was making exceptional efforts to realize Regulation plan of the capital, in order to stop 


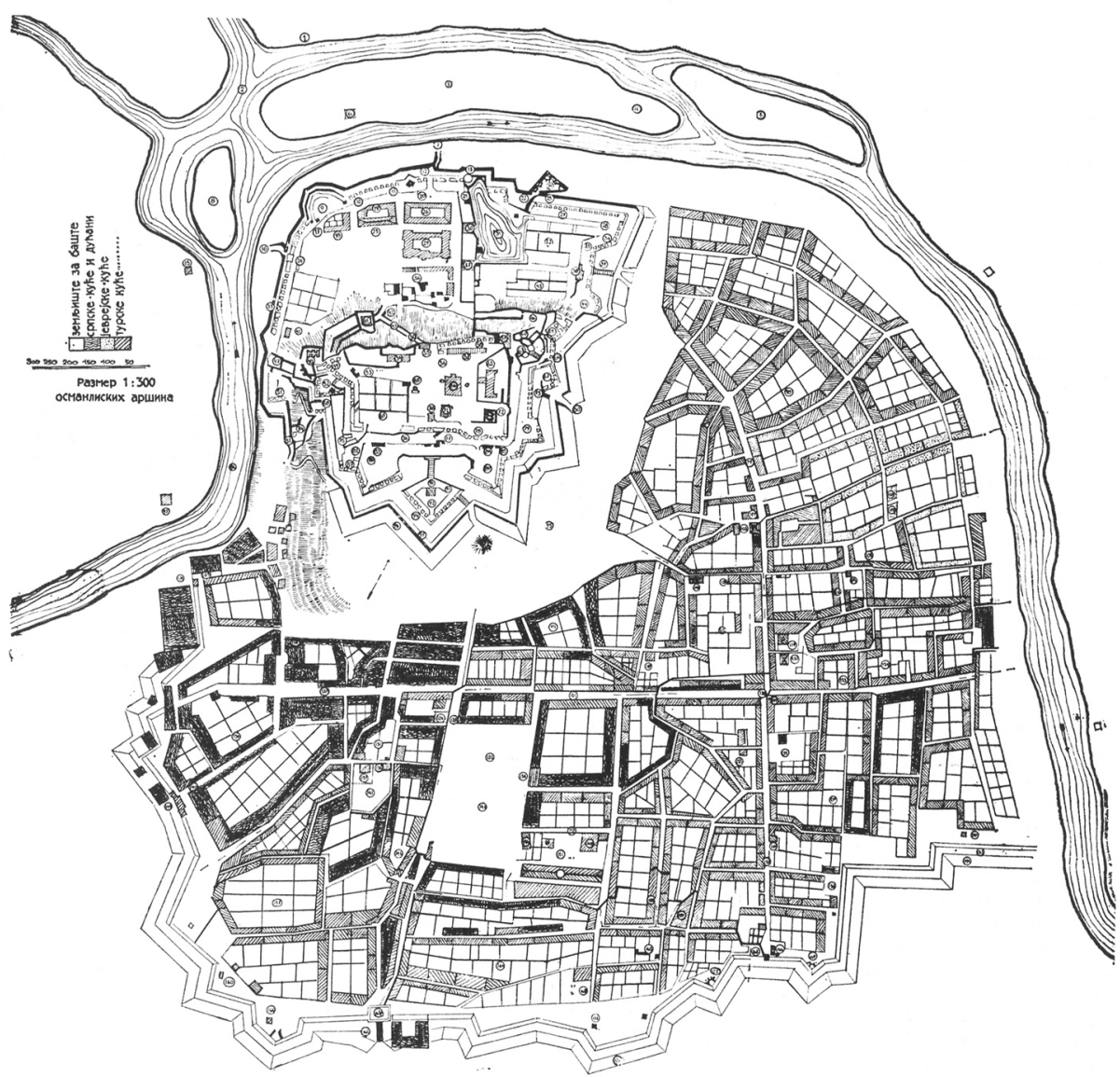

Turski plan Beograda, 1863. (Đurić-Zamolo, 1977. sl. 90)

FigURE 6. THE TURKISH TOWN AND BOROUGH PLAN SURROUNDED BY THE TRENCH, 1863. THE NATIONAL LibRARY OF SERBia, Collection OF MAPS AND PLANS, No. 332.

uncontrolled and irregular development of the Borough and unrestrained illegal constructions. Significant for urban planning regulations were amendments to the „Law about Places“ from 1866 with some new regulations, among those being the obligation of all the cities and towns ,to elaborate plans of regulation and leveling in three years...". By this regulation, the boundaries of settlements were supposed to be defined - city district, where construction regulations would be obligatory, as well as obligation of municipalities for communal infrastructure in the area. 
The main role in solving the issue of future development of the old Borough inside the Trench belonged to Emilijan Josimović (1823-1897), the Lyceum and Velika Škola - The Great School professor and the first Serbian urban planner. (Roter-Blagojević, 1998. pp. 245-258)



Figure 7. “The Old Belgrade (THE PART INSIDE THE TRENCh) AS IT EXISTED AND AS IT IS SUPPosed TO BE REGULATED”, 1867. THE PLAN APPEARS AT THE END OF JOSIMOVIĆ BOOK “JUSTIFICATION OF THE Proposal for Regulating THE AREA OF BELGRAde IN THE MOAT WITH THE Aid OF A LithograPHED Plan, SCALED AT 1:3000" AS AN APPENDIX.

The new Serbian state, slowly and gradually, in parallel steps, was building government administration and developing the city, on the foundations of the Ottoman legacy, but with an anxiety to introduce the indispensable novelties. Still much closer to rural than urban character, by appearance an oriental town, Belgrade got its first public buildings and spaces. The elaboration of the urban plan, the most significant document for regulation of Belgrade Borough in the $19^{\text {th }}$ century, was ordered by Prince Mihailo Obrenović. It follows contemporary trends in Europe and reconstructive works of Baron Georges-Eugene Haussmann in Paris (Harvey, 2003; Pinkney, 1972) and Ildefons Cerdà and Sunyer in Barcelona (Terán, 1999), takes over the idea of Vienna's replacement of the city walls with streets and parks (Blau, Platzer, 1999), 
but still with great difference in inherited urban tissue. The primal ideas of regulatory, beautification, monumentality and theatricality were adapted, modified and individualized for the specific local physical and political conditions, with a goal to establish the national capital, with distinguished role, form and content from other urban centers. (Gunzburger Makaš, Damljanović Conley, 2009. pp. 45-60) That is why Emilijan Josimović, having the educational background at the Viennese Technical University, is called the first Serbian urban planner, possessing unique and confident vision that showed realistic ideas, which was quite remote from utopia. (Tartalja, 1989. p. 9)

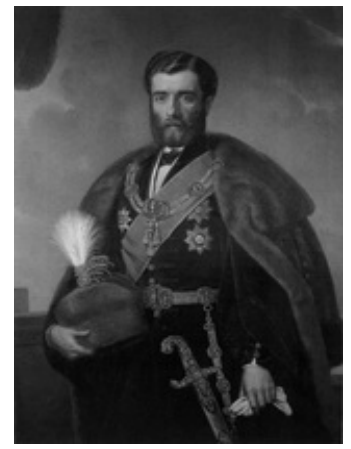

Figure 8. Johan Bes, Portrait of Prince Mihailo OBRENOVIĆ, 1865.

Mihailo OBRENović (1823-1868), THE PRINCE OF SERBIA (1839-1842) AND (1860-1868), THE SON OF PRINCE Miloš AND PRINCESS LJUBICA.

The plan, comprehensive by its nature, is based on the fact that the Turks will leave the city soon and that it is particularly important to modernize (Marković, 1992. pp. 13-33) the part "in the Trench" and connect it within the meanwhile developed new parts at the outskirts of the fortress. The regulation of the new straight line, wider and fluent streets, no more traced just according to the morphology of hills with dead ends, but by forming rectangular city blocks, the creation of public spaces (squares, parks, markets, pedestrian paths and docks) and locations for the public buildings (administration, culture and education, churches), the regulation of housing and commercial dwellings, were main goals, but at the same time, the great change that led to today's appearance of the city historical core. (Maksimović, 1967. pp. 23-32, 35-40) Some topics, such as esthetics, land use, public goods, redirecting traffic to the tunnel, infrastructure needs, healthy environment, could present even a contemporary concern. That was a turning point, the moment when oriental "mahala," (Macura, 1984. pp. 19-25, 74-81; Macura, 1983) which did not recognize the concept of public good and realm in the term of European urban model and style, 
disappeared forever. Although, Josimović was aware of the preservation movement and artistic and historical value of the Ottoman public and religious buildings, he transformed the city skyline by demolition of numerous mosques. (Gunzburger Makaš, Damljanović Conley, 2009, pp. 45-60) The quantity of the implementation of the plan is extraordinary, especially knowing the existing conditions on site and significant changes that were proposed.

After geodetic recording of the old Borough in the Trench, Josimovic performed analysis of the existing situation and new needs for this part of the City. The reconstruction project "Belgrade inside the Trench" together with documentary argumentation of the project, Josimović published as a book. It was the first Serbian professional and theoretic work in the field of urban planning. Josimovićs conception of the overall reconstruction of the old, irregular, typically oriental structure towards the modern European city will influence many cities in Serbia. The only urban block that he did not manage to change and adjust to the orthogonal matrix, due to land ownership, still stands in its triangular form, between the streets Cincar Jankova, Zmaja od Noćaja and Tadeuša Košćuškog.

Instead of wide Vračar fields, Josimović faced the task of creating an entirely new shape of the City in the place of the old Borough. Also, it was necessary to preserve about hundred buildings of greater value, and to entirely change the network of narrow, winding streets difficult for orientation, with about forty blind alleys. Josimović chose to create an organic transportation links between the old and the outer, new borough. Besides the old links via three gates, Josimović created three, new "cart exits" to the Borough, among which the exit in the continuation of Delijska Street (Knez Mihailova) to Terazije was standing out. He suggested construction of the quay around the town, and a basin port by the Danube, out of the river bed. One of the visionary suggestions was the tunnel under the Kalemegdan, which would enable convenient connection between the Sava quay and the Danube port. Among numerous progressive ideas from Josimović's plan, two conceptions stand out. The first was to encircle the old Borough in the Trench with 50,000 sq.m of park space, at the position of the leveled Trench, and the second to arrange the Kalemegdan as the city park, with its dominant position towards the Pannonia plain. 
The plan prepared by Josimović should be considered as General urban plan of the reconstruction, lately accompanied by a series of detailed plans, which partially conducted the basic idea, sometimes with minor deviations. The most famous are the plans A and B plan by Zarić for reconstruction of Knez Mihailova Street and the Plan for regulation of the Great Market and surrounding streets by Šefel. (Škalamera, 1967. pp. 169-201)

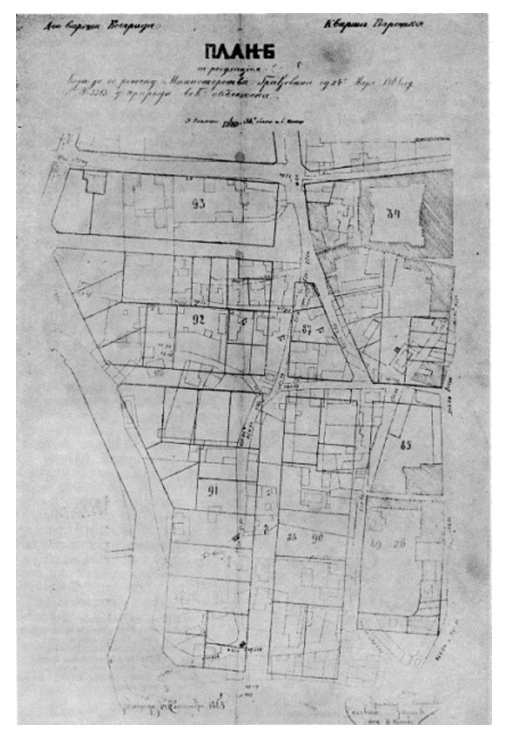

FiguRE 9. PLAN B IS A DETAILED VERSION OF JOSIMOVIC'S PLAN - "PLAN B BASED ON A DECISION ISSUED BY THE MINISTRY OF CONSTRUCTION OF 24 MAY 1868, NO.3313, AND ALREADY MARKED OUT AT THE NATURAL LOCATION, AS EXECUTED BY STEVAN ZARIC", BY WHICH THE SECTION OF KNEZ MiHAilova STREET EXTENDING FROM OBILIĆEV VENAC TO SANU BUILDING (SERBIAN ACADEMY OF SCIENCE AND ART) IS HEREBY REGULATED. SANU ARCHIVES, NO. 7914.

The last three decades of the $19^{\text {th }}$ and the first decade of the $20^{\text {th }}$

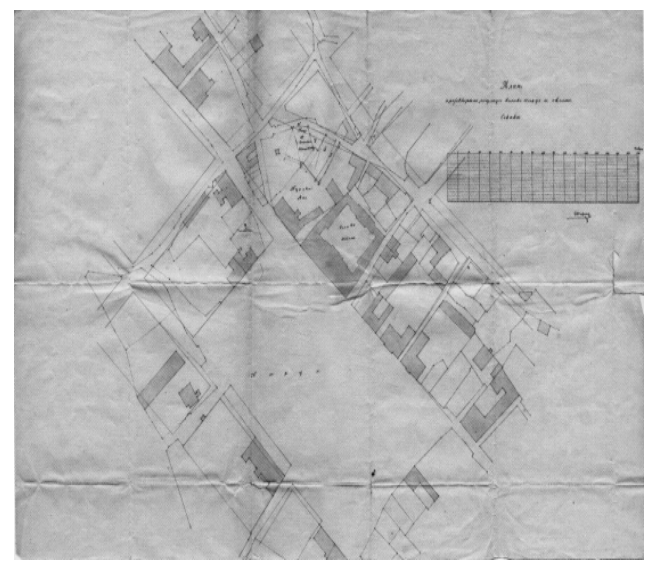

FiguRE 10. PLAN DETAILING THE PROPOSED REGULATION OF THE GREAT MARKET AND SURROUNDING STREETS BY E. ŠEFEL. HAB, SIGN. UVB, FVIP 146.

century were of exceptional importance for the political, social and economic development of Serbia. After the assassination of Prince Mihailo Obrenović in Košutnjak in 1868, the young Milan II Obren- 
ović became the Prince (1854-1901); ruling till 1872 under regency and from then on he took government in his own hands. After the Serbian-Turkish wars (1876-1878), the Treaty of Berlin rewarded his efforts: the territory of Serbia was significantly enlarged, Serbia became a fully independent state and in 1882 Milan was proclaimed the King of Serbia. With that event there started the period of continual social, political and economic development of the young kingdom, lasting till the beginning of the First World War. The rulers in that period were: Milan Obrenović, then his son Alexander (1876-1903), ruling Serbia from 1889 to 1903, when he was assassinated in the "May Coup d'état", and after that from 1903, Petar I Karađorđević (1844-1921). Although this was the period of the dramatic political crises in Serbia, the development was achieved in all spheres of state and social life.

After Josimovićs plan, the first geodetic plan including the entire territory of the city of Belgrade was elaborated in 1878, by the engineer Stevan Zarić.

It was the first Serbian plan presenting the structure of the new Belgrade in Vračar, as far as "Vojničko polje", where General and Military hospitals would be built soon, as well as to the "Slavija“ square. The development of the new city towards the Sava was only temporarily interrupted by the large space of Bara - the pond „Venecija“, because it was filled up soon, due to construction of the railway station. According to the Berlin Treaty, the obligation of Serbia was to build the railroad from the Austro-Hungarian border to the borders with Bulgaria and Turkey. Regulation of the Danube slope was executed as far as Gospodar Jevremova Street. Constructions of the streets Knez Mihailova, Čika Ljubina, Obilićev venac, as well as Zmaj Jovina and Vuka Karadžića as in today's dimensions lasted less than ten years. The village Palilula, with its acute angled streets network and large irregular blocks, became the part of the city territory. The Kalemgedan with its dense network of curved paths was presented as the English style park.

Plan of Belgrade from 1884 includes the same territory as Zarić's plan, though besides the existing situation it includes: the designed streets in Dorćol and in the vicinity of the Railway station, executed regulation on the Danube slope, and the City also spread towards SE with the new settlement "Englezovac" (the land owner - an Englishman Francis McKenzie) with projected new, straight streets: St. Sava, continuation of Njegoševa, Mekenzijeva and Zorina (Knjeginje Zorke) streets. 


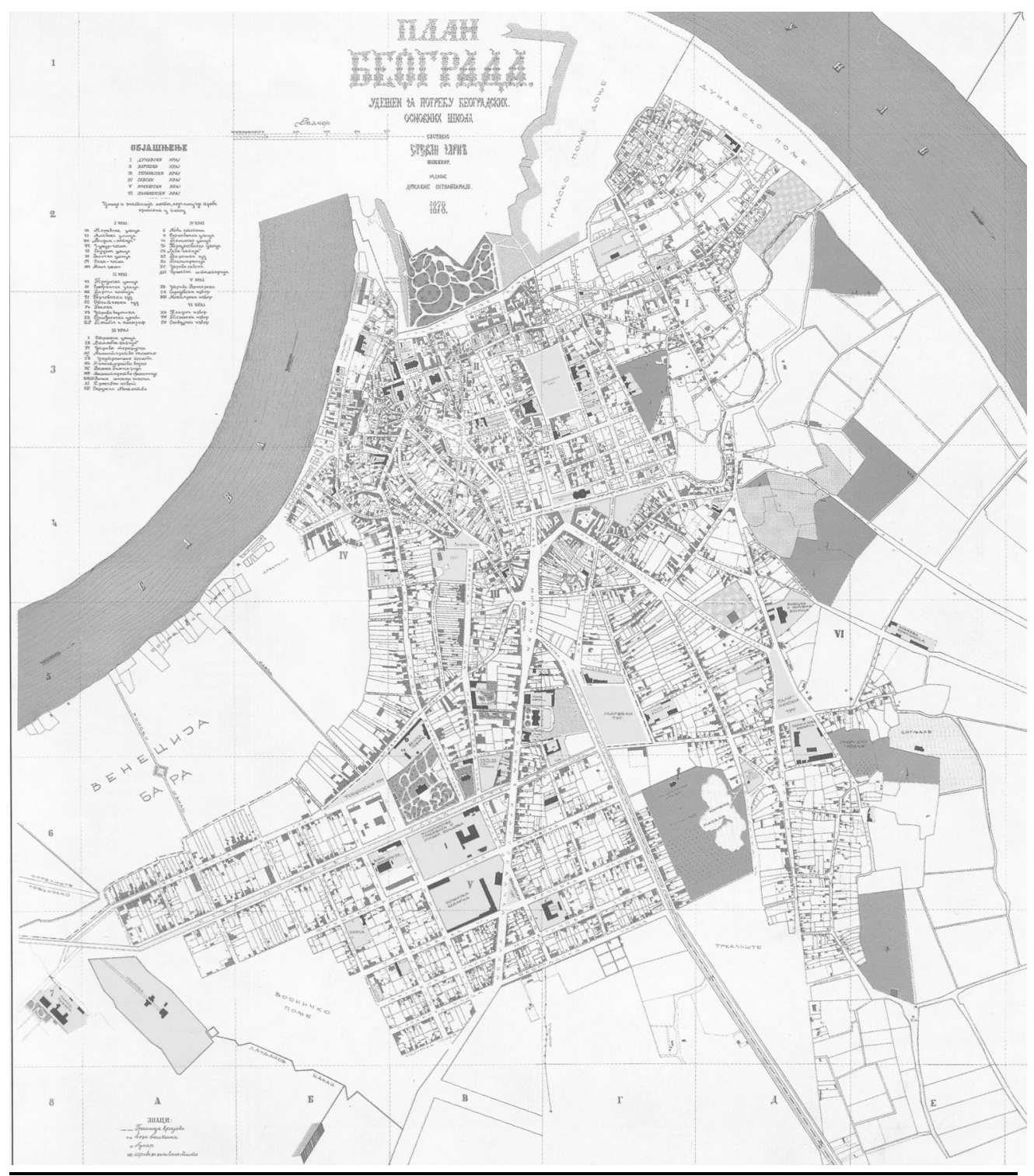

FigURE 11. THE PLAN OF BELGRADE WAS MADE TO MEET THE REQUIREMENTS OF BELGRADE'S PRIMARY SCHOOLS. IT WAS DRAWN BY THE SECOND-CLASS ENGINEER OF Ministry of Public Works, STEVAN ZARIĆ IN 1878. SIGN. KAW, G I B56.

The plan, whose authors were the brothers Šandor and Kalman Halači, the engineers from Budapest, was a part of the contract, according to which they also had to complete the survey and leveling of the streets, green markets and public properties in the 


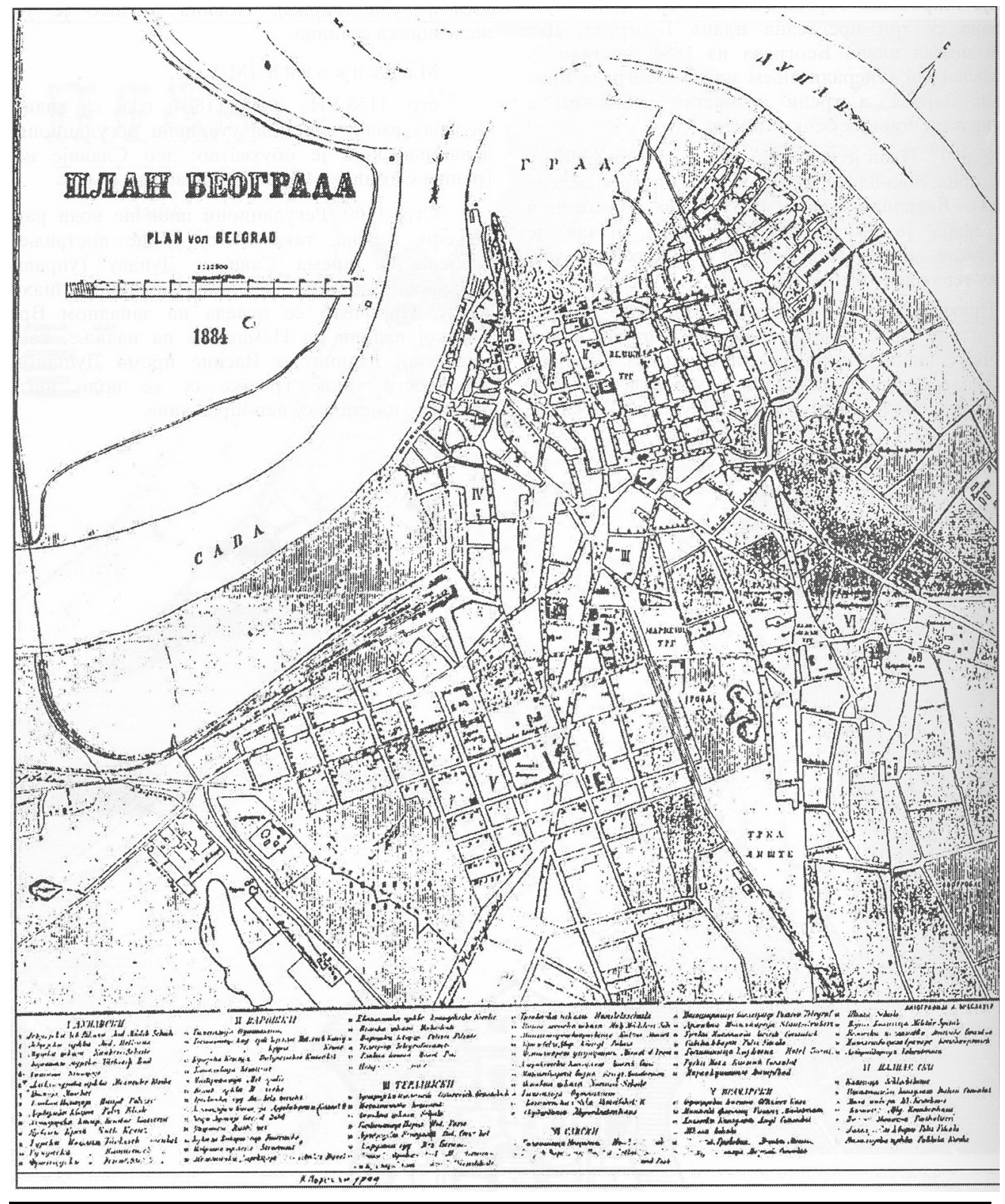

Figure 12. THE Plan OF BeLgRAde FROM 1884. ARCHIVE OF SERbian ACADEMY OF SCIENCE AND ART. LEGACY OF F. KANIC.

city, produce plans and accompanying lists, based on the attached booklet (technical regulations) and urban plan (probably the one 
done by Zarić), with the polygonal grid drawn. The Municipality was obligated under the Law on Municipalities, from 1885-1886 to establish and determine the city area boundaries within one year deadline and in addition to complete the plan for regulation and leveling. During determination of the city area, there started the controversy about the land of Francis Mackenzie, previously called Simićev major, afterwards Selište, Englezovac (today Savinac), because the landowner asked to annex his property to the city area boundaries. In 1885 the survey and determination of the city area limits started. The brothers Halači completed this survey, but they did not finish any situational or leveling drawings. The decision of the Board about finalized determination was established in 1890. (Pajević, 1923. pp. 5-104)

The Plan of Belgrade from 1893, marked „prepared by Bešlić“, is in fact the first integral Regulation plan of Belgrade and as such has an exceptional significance for studying the urban planning genesis in Serbia. The influence of the Danube slope, Josimovićs plan on the significantly larger space of Dorćol and Palilula is obvious, as far as the Danube riverside. New streets network north from Cara Dušana Street is a consecutive continuation of the streets network on the Danube slope. (Đurić-Zamolo, 1981)

In the lower left corner of Bešlić' plan there is the Plan marked "the Surroundings of Belgrade", indicating a wider comprehension of the future growth and development of Belgrade, as well as the significance of the gravitational area for the city life. The „Area boundaries of Belgrade" was plotted with the intention to stop illegal spreading of Belgrade. The fact is that pace of life was always faster than the urban plans, the constant inflow of inhabitants to the city outskirts (usually in unhygienic and illegal settlements of slums), degraded the conditions of the basic urban life. The decision on what belonged to city limits was at numerous times delayed and without this document it was impossible to monitor and implement the development, especially in the segment of infrastructure supply. (Stojanović, 2008)

For the purpose of the research of general change in the development of Belgrade at the end of the $19^{\text {th }}$ century, especially in the hinterland of the city area, the topographic maps in the scale of 1:25000 are very important. (Škalamera, 1967. pp. 169-201) Among them, the Plan of Belgrade stands out, prepared by Captain Mišković, in 1897. It is preserved and kept in the National Library of 


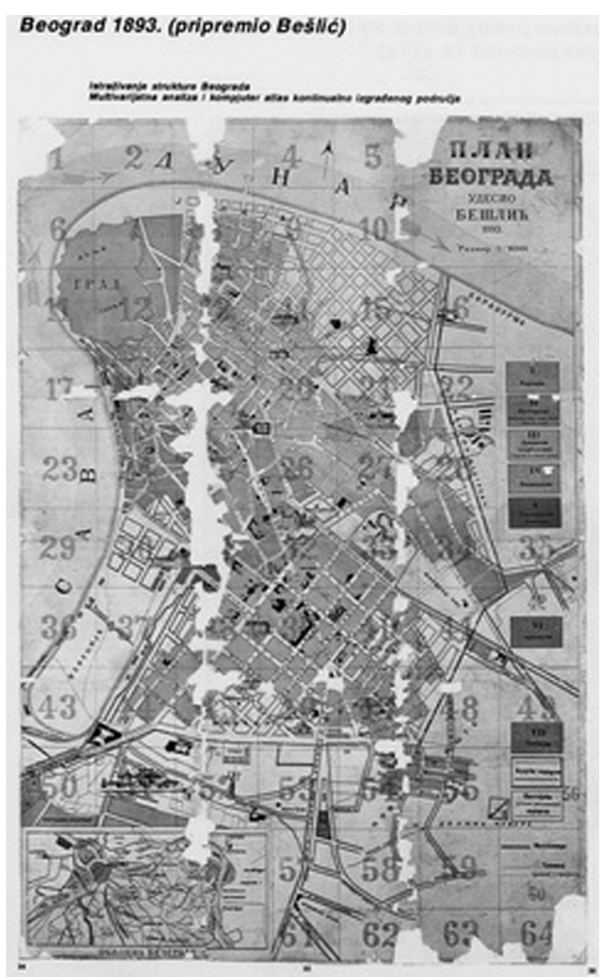

Figure 13. THE Plan OF BELGRADE PREPARED BY (JOVAN) BEŠLIĆ IN 1893. (HISTORY ARCHIVE OF THE City of Belgrade) Sign. KAW, G I B 57-05.

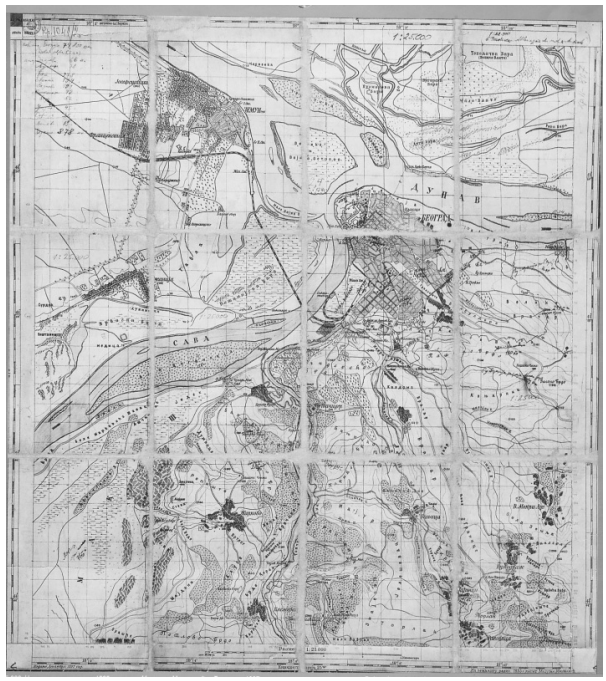

FIGURE 14. THE PLAN OF BELGRADE AND SURROUNDINGS FROM 1897. THE FIELD WORKS CARRIED OUT BY CAPTAIN MILUTIN MIŠKOVIĆ IN 1895. NBS SIGN. KR. II 807.

Belgrade, printed in multicolor technique with very clearly separated elements on one sheet. 
The plan of Belgrade town from 1903, elaborated in Sewerage department of Belgrade Municipality, includes a wider territory than Bešlićs plan and demonstrates that plotted boundary of the town area did not succeed in stopping further spreading of Belgrade towards S-E, the Čuburski and the Bulbuderski creeks. Planned regulation of Dorćol remained the same, while with the railroad embankment towards butchery, spreading towards the right bank of the Danube was physically prevented.

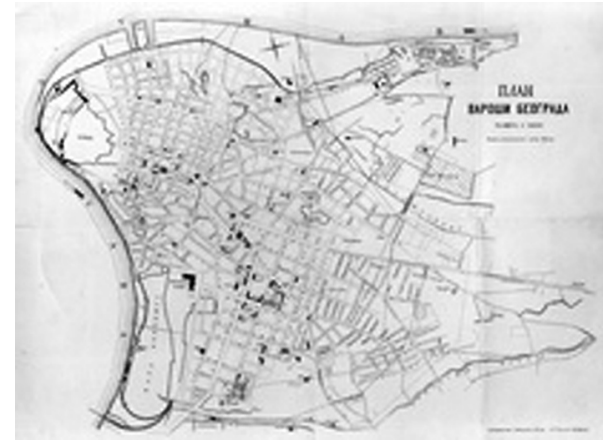

FigURE 15. Plan OF THE

TOWN OF BELGRADE, THE

SEWAGE DEPARTMENT OF THE

BELGRADE CITY

MUNICIPALITY, 1903.

(HISTORICAL ARCHIVE OF THE

City of Belgrade). Sign.

HAB, ZPM I1 4 I I1 5

"Program of Sewerage constructions" was elaborated in 1905 and it was planned that works should be completed by 1911 . The copy of the plan from 1903, where "the schedule of sewerage constructions for 1905-1911" was plotted, clearly demonstrates the influence of the underground communal installations on the project of streets network, which is obvious in the eastern part of Dorćol, where the new modified regulations were under the influence of the designed sewerage network.

\section{THE CULTURAL-POLITICAL CONTEXT OF THE GROWTH AND DEVELOPMENT OF BELGRADE IN THE PERIOD FROM 1815 TO 1910.}

Gradual development of Belgrade started to be achieved after the Second Serbian Uprising in 1815, along with gaining political and national independence inside the Turkish State. In the 1920s Serbian population started to settle in the abandoned Turkish properties and houses inside the Old City. By the time, slowly, it was a singed out Serbian part, nearby the old Serbian Orthodox Church of Saints Archangel Michael and Gabriel (Crkva svetih 
arhanđela Mihaila i Gavrila, at the location of today's Saborna crkva). On this site Prince Miloš erected the first national buildings: the Master's quarters and Archbishopric court (Gospodarski konak, Mitropolitov dvor). Artisans and merchants of Christian origin were directed toward Main downtown (Glavna čaršija, today Kralja Petra street between the Saborna church and Vasina Street), in order to spread even more following the retreat of the Muslim population, to the Danube slope, over Belgrade's reef, until the Great market (today Studentski trg). The settlement on the river Sava slope was expanded in a decade of the 1930s, from the Varoš gate to the waterside of the Sava and towards Terazije. Christian population mostly settled the area outside the Trench, in the locations of Savamala and Palilula. All of this greatly affected the prosperity of building activity in Belgrade. Besides the need for new official and public buildings, there was an aspiration for more extensive residential construction. Special and obvious transition to European buildings could be noticed on examples such as Customs Directorate on the Sava's docks (Uprava carinaĐumrukana), the Assembly in new administrative center (skupštinski dom-Sovjet) and the new nearby Prince's European style residence. Prominent citizens were also building their houses after the European models, such is the house of Cvetko Rajević. (Roter-Blagojević, 2006)

The milestone in the development and construction of Belgrade happened in the last three decades of the 19th century. After the assassination of Prince Mihailo, the power was handed over to the Governorship (Namesništvo) and minor regent Milan Obrenović, when in 1869., the new Constitution was introduced, bringing to Serbia much more liberty and democracy. Prince Milan independently ruled the Principality from 1872 and after the Wars with Turkey (1876-1878) Serbia annexed the southern districts and its autonomy was recognized. In 1882, Prince declared Serbia as hereditary, constitutional and parliamentary monarchy, directing the state to the economic and social prosperity, more and more bringing it closer to the Austro-Hungarian Monarchy. By reason of political instability the king had to abdicate in favor of his minor son Alexander, and the power was handed over to the Governorship again. In 1893, Alexander made a political upheaval and took over the power. Tightening up of the political situation and riots culminated with assassination of the king Alexander Obrenović and 
return of the Karađorđevićs dynasty to Serbian throne. (Istorija Beograda, 1974. pp. 173-186)

In urban plans dating from two last decades of the 19th century the expeditious rate of regulation and construction, as Belgrade's overall transformation, could be noticed. New area, captivated by partial drainage of Venetian pond (Bara Venecija), led to expanding of Savamala territory toward the river Sava (to today's Sarajevska Street) and, also, the regulation of periphery by the city boundary, towards the Danube, in Palilula, in southern and eastern parts of Vračar, was planned. (Nestorović, 1955. pp. 247-266)

Originally established in Lyceum in 1841, teaching of architecture in Serbia was rearranged to Technical Faculty of the Great School. As exemplar of the German polytechnics, in the period from 1896 until 1898 special Architectural Department was organized in the Great School. The prosperity of the city attracted numerous builders, engineers and architects from abroad. Several builders of Serbian origin but born in Austro-Hungarian Monarchy came to Serbia, as the first generation of students born in Serbia, that continued schooling after the Great School abroad, mostly at High Technical schools and academies in Budapest, Wien, Munich and Zurich. (Roter-Blagojević, 1998, pp. 245-258)

From 1804 until 1914 in Serbian architecture different concepts of style were interchanged: after the period of classicism in the 1949s, Serbia adopted the new architectural direction - romanticism. From culturally close Wien there was the recognizable influence, such as one on Kapetan Miša building from 1863. The following period was marked by academic neo-byzantine style (1874-1905), led by Serbian students of the Danish professor Teofil Hanzen (1813-1891). Although the affirmed architects in Serbia since the First World War have had the high education acquired at the prestigious European polytechnic schools and academies, they were not unique in the sense of ideology. Through their work not just different schools were reflected, but conflicts of that time - in political, national and social segment. (Kadijević, 2005. Kolarić, 1966)

At the turn of the centuries it is possible to find new tendencies in stylish understanding of architecture. Serbian architects, although they were changing styles, did not easily become detached from the academic principle of form and structure of the building, so the academic compositional schemes ${ }^{5}$ retained on the building of secession, national style and late romanticism, even in 
later periods in the examples of between the wars modernism or after the War soc-realism. (Kadijević, 2005)

The influence of historical processes on establishing of urbanmorphological forms and structures is of an exceptional significance for the urban heritage of Belgrade. That influence is present even today and is an unavoidable factor for perception of the specific features and authentic spatial entities of the City.

After the liberation from the Turkish occupation, Belgrade became the capital of the Principality and then the Kingdom of Serbia. In 1830s the aspiration for redevelopment and development of Belgrade according to principles of the modern European urban planning was present. This building enthusiasm was inspired by urgent need to form identity of the new state and its capital. In Serbia, the beginning of modern development of settlements, especially towns are associated with the name of the Prince Miloš Obrenović.

Redevelopment of the old Borough inside the Trench started in the second half of the $19^{\text {th }}$ century. City land was greatly enlarged by filling the marshes besides the river Sava. In such a way the amphitheatrically space was obtained, where at its bottom the Railway station was built in 1880s. By the turn of the century, several plans and suggestions for development and spreading of Belgrade and its particular parts were elaborated. The integral conception, suggested in many of these plans, could not be realized. The realization of the urban visions and creative intents depended on key historical, political, social and financial situations and issues. Nevertheless, Serbian towns in the period from 1880s till the end of the first decade of $20^{\text {th }}$ century were steadily built.

The urban heritage of Belgrade from the point of view of cultural-historical values consists of structures and entities, though also architectural complexes, city districts and areas of the specific, ambient, style and environmental values. Besides historical layers of the Balkans, Belgrade unites the influences of the Central Europe, Austrian and German urban planning, English heritage

The period of the Serbian architectural academicism, as one of the styles of the epoch of historicism, includes three time units: the first period of early and strict academicism (1865-1900), the second, with predomiant liberal understanding of formal norms (1900-1914), and the third, late period (1918-1950), in which academicism converted in shape of modernized academic monumentalism. More about this in: Kadijević, 2005. p. 297. 
from the end of the $19^{\text {th }}$ and beginning of the $20^{\text {th }}$ century, as well as program conceptions of the European Modernism.

REFERENCES Belgrade: Maps and Plans from the $18^{\text {th }}-21^{\text {st }}$ century. Belgrade: Urban Planning Institute of Belgrade.

Bajalović-Hadži Pešić, M. (1977). Srednjovekovnom Beogradu u pohode. Beograd: Muzej grada Beograda.

Blau, B., Platzer, M. (Eds) (1999). Shaping the Great City. Munich: Prestel.

Bojović, B. (2002). “Urbanizam Beograda u XIX i XX veku”. Godišnjak grada Beograda br. 49-50, pp 109-130.

Vujović, B. (1986). Umetnost obnovljene Srbije 1791-1848. Beograd: Prosveta.

Dervitchevitch, C. (1939). Evolution de Belgrade. Paris: Jouve.

Dimitrijević, S. (1986). Pozdrav iz Beograda. Beograd: Zavod za zaštitu spomenika kulture grada Beograda.

Đurić-Zamolo, D. (1981). Graditelji Beograda 1815-1914. Beograd: Muzej grada Beograda.

Gunzburger Makaš, E., Damljanović Conley, T. (2009). Capital Cities in the Aftermath of Empires - Planning in Central and Southeast Europe. London: Routledge.

Kadijević, A. (2005). Estetika arhitekture akademizma (XIX-XX vek). Beograd: Građevinska knjiga.

Kojić, B. (1976). Stari balkanski gradovi, varoši i varošice. Beograd: ICS.

Kolarić, M. (1966). Klasicizam kod Srba, knj. 2. Gradjevinarstvo. Beograd: Narodni muzej.

Krasojević, M. (2004). Katalog planova i karata Beograda. Beograd: Geokarta.

Kurtović Folić, N. "Different origins of the Settlements of Oriental Type in Serbia". SPATIUM International Review, No. 6, 2000, pp. 15-21

Macura, V. (1984). Čarsija i gradski centar u Srbiji XIX i prve polovine XX veka. Niš: Gradina, Svetlost.

Macura, V. (1983). Urbano planiranje u Srbiji XIX i XX veka. Beograd: Urbanistički zavod Beograd.

Maksimović, B. (1967). Emilijan Josimović, prvi srpski urbanista. IAUS.

Maksimović, B. (1978). “Idejni razvoj srpskog urbanizma”. Spomenik CXXI, pp. 31-70.

Marković, P. J. (1992). Beograd i Evropa 1918-1941, evropski uticaji na proces modernizacije Beograda. Beograd: Savremena administracija.

Nestorović, B. (1954). "Razvoj arhitekture Beograda od Kneza Miloša do Prvog svetskog rata 1815-1914”, Godišnjak Muzeja Grada Beograda, knj. I, 1pp. $159-174$. 
Pajević, B. M. (1923). Regulacija Beograda 1867-1923, Beograd: Narodna misao. Perović, M. (1997). “Istorija moderne arhitekture”. In: Antologija tekstova knj.1 (pp. 276-349). Beograd.

Pinkney, D. H. (1972). Napoleon III and the Rebuilding of Paris. Princeton, NJ: Princeton University Press.

Tričković, R. (1973). "Beogradska tvrdjava i Varoš 1739-1789. godine”. Godišnjak Grada Beograda, knj. XX, pp. 49-87.

Roter-Blagojević, M. (1998). "Pojava prvih zakonskih propisa i standarda u oblasti gradjevinarstva u Srbiji tokom 19. početkom 20. veka”. Izgradnja br. 5 , pp. 245-258.

Stojanović, D. (2008). Kaldrma i asfalt, urbanizacija i evropeizacija Beograda 18901914. Beograd: Udruženje za društvenu istoriju.

Tartalja, I. (1989). Beograd XXI veka, iz starih utopija i antiutopija. Beograd: srpska književna zadruga.

Terán, F. de (1999). Historia del urbanismo en España, vol. III, Siglos XIX y XX: 3. Madrid: Ediciones Cátedra.

Harvey, D. (2003). Paris, Capital of Modernity. London: Routledge.

Škalamera, Ž. "Planovi Beograda iz prve polovine XIX veka”. Urbanizam Beograda br. 26, 1974, pp. 9-14.

Škalamera, Ž (1967). "Prilog proučavanju kartografskih izvora iz istorije Beograda 19. veka”. Godišnjak Grada Beograda, knj. XX, pp. 169-201.

Orion Art, Faculty of Architecture of the University of Belgrade, 2006.

Istorija Beograda, knj. 2. Beograd: SANU, 1974. pp.173-186. 
МАРТА М. ВУКОТИЋ ЛАЗАР

УНИВЕРЗИТЕТ У ПРИШТИНИ С ПРИВРЕМЕНИМ СЕДИШТЕМ

У КОСОВСКОЈ МИТРОВИЦИ, ФИЛОЗОФСКИ ФАКУЛТЕТ

КАТЕДРА ЗА ИСТОРИЈУ УМЕТНОСТИ

НАТАША М. ДАНИЛОВИЋ ХРИСТИЋ

УРБАНИСТИЧКИ ЗАВОД БЕОГРАДА

РЕЗИМЕ

РАСТ И РАЗВОЈ БЕОГРАДА У ПЕРИОДУ ОД 1815. ДО 1910. GОДИНЕ

Београд је рушен и обнављан небројено пута. Разне културе, народи и освајачи оставили су за собом различите урбане матрице и физичку структуру. Кључни основ за сагледавање и проучавање урбаних матрица, као битних елемената урбане морфологије Београда су графичке представе - старе карте и планови. С обзиром на стратегијску важност коју је Београд имао до 19. века, графички прикази тога периода углавном су били усмерени на подручје Београдске тврђаве, док је цивилно насеље варош у Шанцу, мала оријентална варош, приказивана само оријентационо.

Рад се ठави пионирским замислима у домену планске изградње Београда, како у окврима, тако и ван Шанца, од почетка 19. до почетка 20. века. Посебан акценат је стављен на период владавине кнеза Милоша обреновића, када и започиње период планске изградње геометријски регулисаног новог београдског насеља на Западном Врачару (ван Шанца), који је требало повезати са центром српског Београда (у Шанцу) око данашње Саборне цркве, преко већ тада трасираних улица Аठаџијске и Фишеклијске.

Почетком 19. века док су се за превласт над Београдом борили Запад и Исток, између њих се „умешала“ трећа сила : Нова српска држава. На релацији између Клемегданског поља и Топчидера, Срби су у доба Милоша обреновића заузели стратешеке тачке, распоредили своје јавне установе, своју чаршију и стамбене објекте дуж главних комуникација. Изградња Новог српског Београда започела је крајем прве четвртине 19. века у савском крају у оквирима Шанца, а који се простирао од данашњег Косанчићевог венца, Топличиним и обилићевим венцем до Трга Републике, а онда се Француском улицом спуштао до Дунава. Нова изградња је започела у оквиру Шанца, али се врло брзо проширила на простор ван њега. Изван Шанца су се налазиле Савска варош и село Савамала, испод Ташмајдана се простирало 
село Палилула, а око Скадарске улице и Зеленог венца су биле две циганске махале. У периоду од 1835-1938. године Кнез Милош је почео плански да подиже у овом простору значајне зграде и установе обновљене Кнежевине Србије, а после 1860. године изградњу овог дела града наставља његов син Кнез Михаило обреновић. Планом су већ тада предвиђене Немањина улица и прво ठеоградско шеталиште, улица Кнеза Милоша, а која је и данас симбол градског живота у престоници.

Након турске предаје тврђаве српској управи 1867. године, ослобођени Београд улази у нови период урбанистичког и архитекотнског развоја, као и убрзаног политичког, економског, друштвеног и културног напредка. Први српски урбаниста Емилијан Јосимовић је реконстрисао варош у Шанцу, а чије су поставке скоро у целости реализоване. То је уједно и период опсежних трансформација српске престонице, а након проглашења Краљевине 1882. године уследиће и бројне стране инвестиције. На старим плановима и фотографијама могуће је уочити ту снажну трансформацију Београда, тачније његово прерастање у модерни град западне оријентације.

Пресудан догађај не само за политички, већ и за културни развој Београда и Србије, била је драматична промена династије 1903. године. Доласком на престо Петра I Карађорђевића, Београд се све више удаљавао од аустријских утицаја, и окретао ка Русији, међутим утицај западноевропских градова на српску архитектуру и урбанизам ипак није јењавао. Политички и културни утицаји Истока и Запада, уткани у идентитет Београда, најјасније су се изражавали управо на овом пољу и то кроз сталну борбу традиционализма и модернизма, конзервативних и прогресивних тенденција.

КључнЕ РЕчи: урбанистичко наслеђе, архитектура, историја, морфологија. 